\title{
Short note on a pteranodontoid pterosaur (Pterodactyloidea) from western Queensland, Australia
}

\author{
ALEXANDER W.A. KELLNER ${ }^{1,2,3}$, TAISSA RODRIGUES ${ }^{1,2}$ and FABIANA R. COSTA ${ }^{1,4}$ \\ ${ }^{1}$ Setor de Paleovertebrados, Museu Nacional/UFRJ, Quinta da Boa Vista s/n \\ São Cristóvão, 20940-040 Rio de Janeiro, RJ, Brasil \\ ${ }^{2}$ Fellow CNPq \\ ${ }^{3}$ Fellow FAPERJ \\ ${ }^{4}$ Fellow CAPES
}

Manuscript received on December 9, 2010; accepted for publication on January 5, 2011

\begin{abstract}
Flying reptiles from Australia are very rare, represented mostly by isolated bones coming from the Early Cretaceous (Albian) Toolebuc Formation, which crops out in western Queensland. Among the first pterosaur specimens discovered from this deposit is a mandibular symphysis that some authors thought to have a particular affinity to species found in the Cambridge Greensand (Cenomanian) of England. It was further referred as a member of or closely related to one of the genera Ornithocheirus, Lonchodectes or Anhanguera. Here we redescribe this specimen, showing that it cannot be referred to the aforementioned genera, but represents a new species of pteranodontoid (sensu Kellner 2003), here named Aussiedraco molnari gen. et sp. nov. It is the second named pterosaur from Australia and confirms that the Toolebuc deposits are so far the most important for our understanding of the flying reptile fauna of this country.
\end{abstract}

Key words: Pteranodontoidea, Pterosauria, Toolebuc Formation, Cretaceous, Australia.

\section{INTRODUCTION}

To date, pterosaur findings in Australia are quite rare, being recovered in only a few deposits (Kear et al. 2010, Kellner et al. 2010; Fig. 1). The most important finds are from the marine Lower Cretaceous (Albian) Toolebuc Formation, western Queensland, which has yielded several isolated remains (e.g., Fletcher and Salisbury 2010). The first report on flying reptiles from this unit was made by Molnar and Thulborn (1980) who described three specimens, all housed in the Queensland Museum (QM): a mandibular symphysis (QM F10613), an incomplete vertebra (QM F10614), and a left scapulocoracoid (QM F10612). From these, the most interesting is the lower jaw (QM F10613), first regarded as representing

Proceedings of the Third Gondwanan Dinosaur Symposium Correspondence to: Alexander Wilhelm Armin Kellner E-mail: kellner@mn.ufrj.br a species closely related to Ornithocheirus Seeley, 1869 (Molnar and Thulborn 1980). This interpretation was questioned by Unwin et al. (2000) who regarded the Australian lower jaw as Anhanguera? cuvieri (see also Unwin 2001). Molnar and Thulborn (2007) later referred this specimen to Lonchodectes Hooley, 1914, and recently Myers (2010) referred it as aff. Ornithocheirus. This disagreement is mainly based on the problematic on how to define several taxa of the Cambridge Greensand (Cenomanian) of England, to which this Australian species is regarded to be related. Here we review this lower jaw (QM F10613) and show that it is not referable to Ornithocheirus, Lonchodectes or Anhanguera, but represents a new taxon, which we name Aussiedraco molnari gen. et sp. nov. 


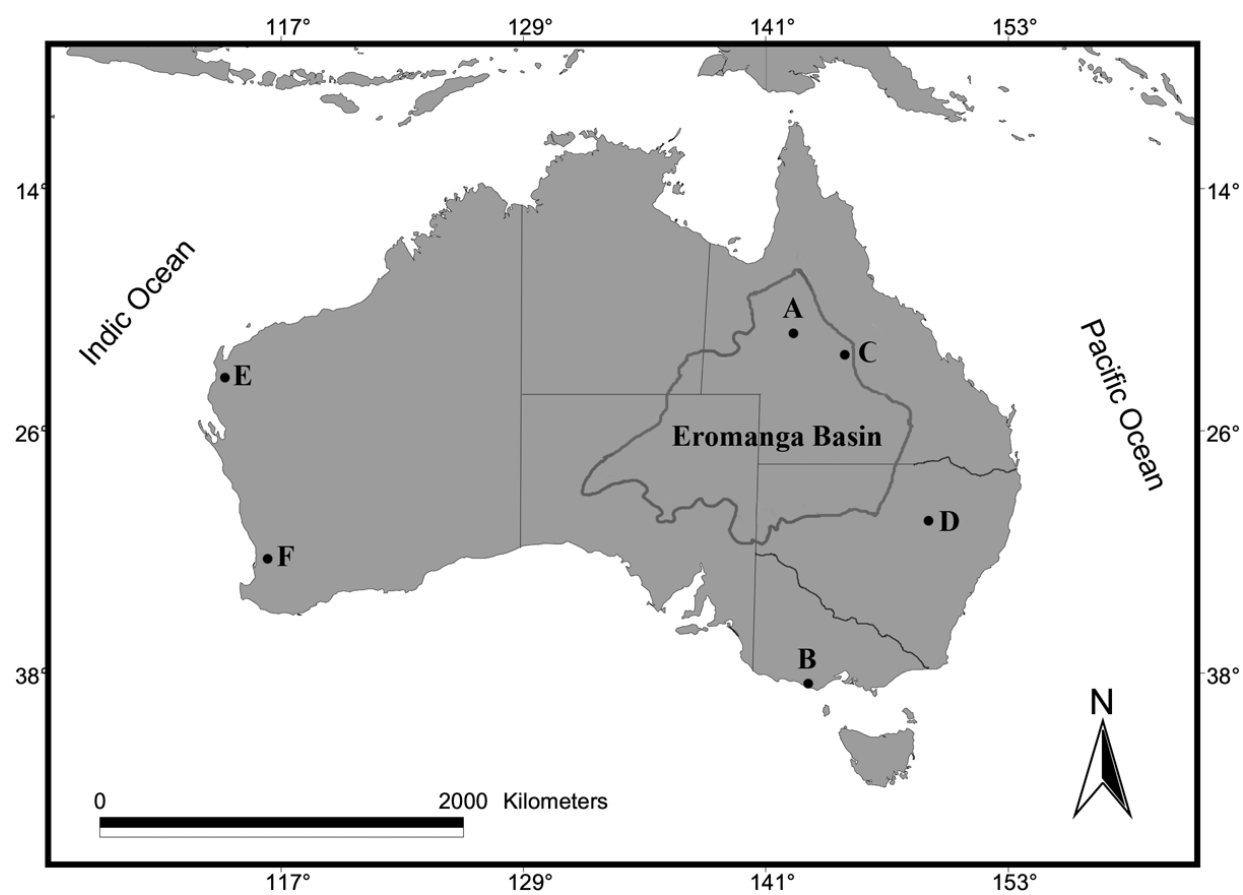

Fig. 1 - Australian pterosaur sites: (A) Toolebuc Formation (Albian); (B) Dinosaur Cove (Aptian/Albian); (C) Winton Formation (Albian); (D) Lightning Ridge (Albian); (E) Miria Formation (Maastrichtian); and (F) Molecap Greensand (Cenomanian/Conician). Adapted from Molnar and Thulborn (2007).

\section{INSTITUTIONAL ABBREVIATIONS}

CAMSM - Sedgwick Museum of Earth Sciences, Cambridge, England.

MN - Museu Nacional, Universidade Federal do Rio de Janeiro, Rio de Janeiro, Brazil.

NHMUK - Natural History Museum, London, England. QM - Queensland Museum, Brisbane, Australia.

SMNS - Staatliches Museum für Naturkunde, Stuttgart, Germany.

SMU - South Methodist University, Dallas, USA.

WAM - Western Australian Museum, Perth, Australia.

\section{SYSTEMATIC PALEONTOLOGY}

Pterosauria Kaup, 1834

Pterodactyloidea Plieninger, 1901

Pteranodontoidea Marsh, 1876

(sensu Kellner 2003)

Aussiedraco gen. nov.

Etymology: Aussie, a shortened form of Australian and draco, from Latin meaning dragon.
Type-species: Aussiedraco molnari sp. nov., type by monotypy.

Diagnosis: As for the type species.

Aussiedraco molnari sp. nov.

Etymology: The species name honors Ralph E. Molnar who made many important contributions to our knowledge of Australian vertebrate fossils.

Holotype: Partial mandibular symphysis housed at the Queensland Museum (QM F10613), Brisbane, Australia; cast at the Museu Nacional (MN 4721-V), Rio de Janeiro, Brazil.

Locality and horizon: According to Molnar and Thulborn (1980), the specimen was collected some $13 \mathrm{~km}$ south of Hamilton Hotel, about $70 \mathrm{~km}$ east of Boulia, western Queensland, and comes from the Toolebuc Formation (Albian).

Diagnosis: Pteranodontoid pterosaur with the following combination of characters that distinguishes it from other members of this clade (autapomorphies are marked 
with an asterisk): dorsal margin of mandibular symphysis markedly convex*, ventral margin of the symphysis straight*, distal end of the symphysis not expanded laterally, mandibular symphysis slightly deeper than wide, deep but narrow dorsal sagittal groove that does not reach the tip of the mandibular symphysis, alveoli sub-equal in size.

\section{DESCRIPTION}

The specimen QM F10613 (Fig. 2) is three-dimensionally preserved and comprises the anterior part of a long mandibular symphysis, with $88 \mathrm{~mm}$ in length. As is common in pterosaurs, the mandible is lightly built, with very thin bone cortex. The presence of a narrow midline groove confirms that the fossil represents a lower jaw. The transversely convex dorsal surface is marked by this groove that runs towards the anterior part of the symphysis but does not reach its tip (Fig. 2b, c). The lateral surfaces are flat and slightly bent inwards at about $40^{\circ}$. These surfaces meet ventrally to form a sharp edge without either expansions or crests, resulting in a triangular cross-section that is somewhat deeper than wide.

The right dental margin bears five alveoli, none of them with teeth. The left dental margin bears four complete alveoli and the remains of a fifth one paired with the fifth of the right margin (Fig. 2c). The curvature of the dorsal surface reaches its maximum height ventral to the fourth pair of alveoli from where it decreases in depth both anteriorly and posteriorly (Fig. 2a, b). The alveoli are elliptical, longitudinally longer in shape, with relatively similar sizes of their anteroposterior diameters and forming distinct bulges in the dental margins. Their size and structure indicate an isodont dentition at the front of the symphysis. As reported in the original description (Molnar and Thulborn 1980), only the fourth alveolus contains a small, incompletely erupted replacement tooth with a thin, lateromedially compressed crown. This tooth does not fill its alveolus, and thus represents a replacement stage after the loss of the former functional tooth (Edmund 1960).

Dorsally, the dental margins are quite straight between the fourth and fifth alveoli and become slightly to strongly scalloped between the third and the fourth alveoli and the third and the second ones, respectively.
This arrangement could allow an interlocking of the upper and lower teeth (Molnar and Thulborn 2007) mainly at the tip of the symphysis. The first to the fourth alveoli face more dorsolaterally, while the fifth alveolus face more dorsally. This arrangement could have projected the anteriormost teeth outwards, with the first alveoli probably carrying near-procumbent teeth. The spacing between the first and the second alveoli is smaller compared to the other well-spaced ones, with the fourth and fifth alveoli being more separated from each other.

\section{DISCUSSION}

The elongate mandibular symphysis shows that the specimen is a member of the Pterodactyloidea (Archaeopterodactyloidea + Dsungaripteroidea), since non-pterodactyloid pterosaurs either have a very short mandibular symphysis or no symphysis at all (e.g., Kellner 2003, Unwin 2003, Wang et al. 2009, 2010). Regarding the fact that it is a toothed pterosaur, a taxonomic assignment for this specimen excludes most of dsungaripteroids, except the Pteranodontoidea. According to Kellner (2003) this clade comprises Pteranodon (Pteranodontidae), the Istiodactylidae, Ornithocheirus and the Anhangueridae. Pteranodon and other members of the Pteranodontidae are toothless (e.g., Bennett 1994, Kellner 2010) and therefore Aussiedraco molnari is excluded from this clade. The shape of the alveoli and the sole preserved replacement tooth clearly show that the Australian species is also not a member of the Istiodactylidae that includes species with a peculiar dentition formed by strongly laterally compressed teeth with a triangular crown (Howse et al. 2001, Andres and Ji 2006, Wang et al. 2008). Furthermore, Aussiedraco molnari is also not a member of the Anhangueridae that is characterized by the presence of a dentary crest and by having the symphysis expanded (e.g., Kellner 2003).

Aussiedraco molnari also differs from all other toothed pterosaurs that are regarded as members of the Pteranodontoidea (sensu Kellner 2003) such as Ludodactylus sibbicki and Brasileodactylus cf. araripensis (Sayão and Kellner 2000, Frey et al. 2003) due to the presence of a convex dorsal surface of the lower jaw.

In comparison with pterosaur material from the Cambridge Greensand of England, Molnar and Thulborn (1980) identified QM F10613 as an ornithocheirid, 

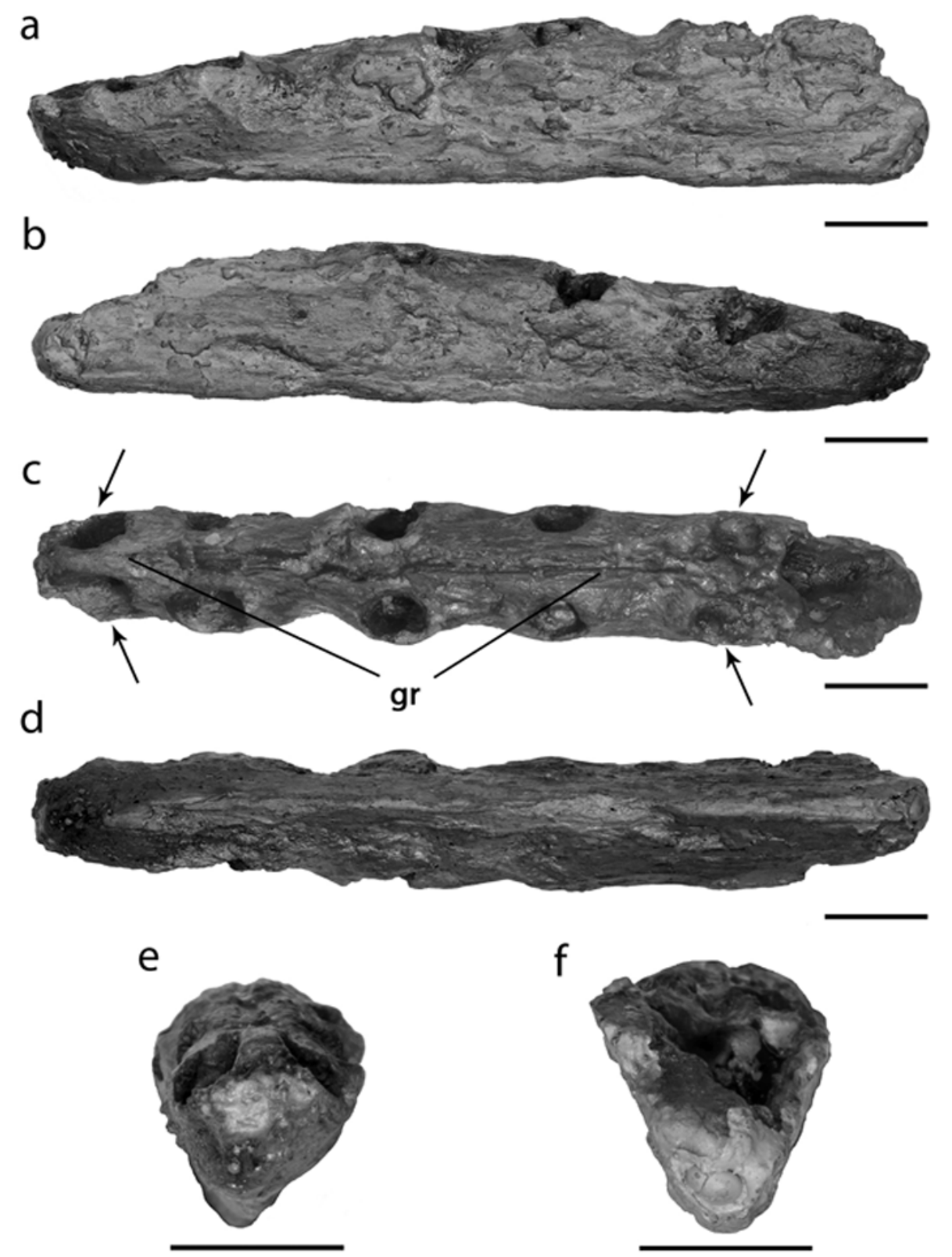

Fig. 2 - Aussiedraco molnari gen. et sp. nov. from the Toolebuc Formation, western Queensland, Australia. Cast (MN 4721-V) of the holotype (QM F10613). Mandibular symphysis: a, left lateral; $\mathrm{b}$, right lateral; c, dorsal; d, ventral; e, anterior and f, posterior views. Setae indicate the first and last alveoli on each side. Abbreviation: gr-groove. Scale bar: $10 \mathrm{~mm}$.

as aff. Ornithocheirus sp. More recently, in light of new publications (i.e., Unwin 2001), these authors reevaluated their initial assignment and regarded the Australian material as pertaining to the genus Lonchodectes or to a closely related form (Molnar and Thulborn 2007). On the other hand, Unwin et al. (2000) have previously assigned the Australian lower jaw to Anhanguera? cuvieri and recently Myers (2010) referred it to aff. Ornithocheirus.

Although the taxonomy of the so called Ornithocheirus-complex still badly needs to be sorted out (Unwin 2001), some comparisons between these taxa and 
the Australian species can be made. Only upper jaws can be doubtlessly referred to Ornithocheirus simus and therefore the comparisons with Aussiedraco are limited. Although Ornithocheirus simus resembles Aussiedraco in not possessing a distal expansion of the skull, in the former the distal end is more rounded, suggesting that also the lower jaw might have had this shape, which differs from the relatively lanceolated mandibular tip present in the Australian material.

The Lonchodectidae sensu Unwin (2001) includes species that share the presence of small, uniformly spaced teeth, with a wide dorsal groove on the lower jaw, features that contrast with Aussiedraco molnari. The type material of Lonchodectes compressirostris (NHMUK PV 39410) includes a heavily compressed mandibular symphysis, which presents oval alveoli, in contrast to the more elliptical alveoli present in QM F10613. Lonchodectes giganteus (holotype NHMUK PV 39412) differs from QM F10613 by the rounded tip of the mandible, by the presence of a mandibular crest, and by an elevated alveolar margin. Lonchodectes machaerorhynchus (holotype CAMSM B54855) is known by a very distinctive piece of the mandibular symphysis lacking the tip. It differs from the Australian material by the presence of a thin crest and a much larger mandibular groove. The type specimens of Lonchodectes microdon (holotype CAMSM B54486) and of Lonchodectes platystomus (CAMSM B54835) comprise only upper jaws (Seeley 1870), while the holotype of Lonchodectes sagittirostris (NHMUK PV R 1823) has only mandibular rami preserved, lacking a symphysis. Thus, these species cannot be objectively compared to QM F10613. The same applies for "Ornithocheirus" cuvieri whose holotype is an upper jaw (NHMUK PV 39409). Although the review of the Cambridge Greensand pterosaur fauna is beyond the scope of this paper, we would like to note that "Ornithocheirus" cuvieri lacks the expanded distal end of the premaxillae and the tooth disparity typical of Anhanguera, and we see no grounds to refer this species to this genus, as previously done (Unwin 2001).

There is an overall similarity between Aussiedraco molnari and several lower jaws from the Cambridge Greensand of England, which cannot be objectively referred to any taxa (for instance, specimens NHMUK PV
R 540, R 2277, 35412a; CAMSM B 54893). The tips of the symphyses are lanceolate and size differences among the alveoli are not very discrepant. Although NHMUK PV R 540 and R 2277 are too fragmentary to evaluate if they had similar tooth spacing patterns as Aussiedraco, in NHMUK PV 35412a and CAMSM B 54893 the spaces between the second to the fifth alveoli are not larger than their diameters. Furthermore, the dorsal surface of the lower jaw in both is straight and the ventral margin convex, thus differing from the Australian species.

Outside England, other specimens were referred to Ornithocheirus or the Ornithocheiridae. Among these is "Ornithocheirus" wiedenrothi (holotype SMNS 56628) from Germany that differs from Aussiedraco molnari by the curved ventral margin of the lower jaw, lacking the convex dorsal margin, and by the presence of a welldeveloped and sharp process on the tip of the symphysis (Wild 1990).

Recovered from Upper Cretaceous deposits of Texas and referred to the Ornithocheiridae, Aetodactylus halli (holotype SMU 76383) differs from Aussiedraco molnari by the great number of teeth, which are more closely spaced, and by being strongly compressed dorsoventrally (Myers 2010).

Regarding other pterosaur material from Australia, most consists of isolated elements that are not comparable with the lower jaw of Aussiedraco molnari (see Kellner et al. 2010 for a review). Molnar and Thulborn (2007) erected Mythunga camara that was regarded as a member of the Archaeopterodactyloidea, but Kellner et al. (2010) relocated this species to the Pteranodontoidea, closely related to (but not a member of) the Anhangueridae or Onithocheiridae (the latter needing redefinition). Comparisons with Aussiedraco molnari are limited since Mythunga camara lacks the distal ends of the jaws. Nevertheless, Mythunga camara belongs to a comparatively larger animal and has the preserved portion of the mandibular symphysis comparatively deeper than Aussiedraco molnari. We agree with Molnar and Thulborn (2007) that Mythunga camara and the lower jaw QM F10613 (the holotype of Aussiedraco molnari) belong to distinct taxa.

Very recently, Fletcher and Salisbury (2010) described a few more pterosaur isolated remains from the Toolebuc Formation, including the anterior part of a 
mandibular symphysis (QM F44423). The material is apparently less preserved than the holotype of Aussiedraco molnari (QM F10613), lacking the distal end and most of the ventral portion. Based on the published pictures, QM F44423 has the dorsal and ventral margins of the mandibular symphysis respectively, straight and convex, quite the contrary to the condition observed in Aussiedraco molnari.

Another Australian jaw fragment (WAM 68.5.11) was described by Kear et al. (2010) and comes from the Upper Cretaceous (Cenomanian/Coniacian) Molecap Greensand. This material is extremely fragmentary and it is not possible to determine if it belongs to the upper or lower jaw. WAM 68.5.11 presents two consecutive alveoli and, based on their morphology, the authors have identified it as an ornithocheirid (sensu Unwin 2003) or an anhanguerid (sensu Kellner 2003). These alveoli are more separated from each other than the ones preserved in Aussiedraco molnari, but a wider separation should be expected if this fragment comes from a more posterior portion of the jaw. As both specimens come from different lithostratigraphical units and have different ages, they possibly do not represent the same species (see discussion in Kellner 2010), although more complete material is in need to better evaluate this matter.

\section{CONCLUDING REMARKS}

Although the potential for more complete pterosaur findings is present in the Toolebuc Formation, for over three decades since the first discovery (Molnar and Thulborn 1980) only fragmentary and isolated remains have been found (Kellner et al. 2010, Fletcher and Salisbury 2010), similar to what has been observed in other deposits such as the Tendaguru layers (e.g., Costa and Kellner 2009) and the Kem Kem beds of Morocco (e.g., Wellnhofer and Buffetaut 1999). As a result, authors named new species based on incomplete specimens (e.g. Unwin and Heinrich 1999, Ibrahim et al. 2010) if a diagnostic combination of characters could be found (see Kellner 2010). Having a fossil record composed of incomplete material is particularly the case of Australian deposits (e.g., Rich and Rich 1989), including the Toolebuc Formation, where several species have been based on isolated elements (e.g., Molnar and Pledge 1980).
Based on the above comparisons, we conclude that QM F10613 neither can be referred to Ornithocheirus nor can be stated as Lonchodectes or Anhanguera due to the dentition, lack of dentary crest and the outline of the mandibular symphysis. The size and shape of the alveoli and the presence of a midline groove indicate that the Australian species is a member of the Pteranodontoidea, occupying a more derived position relative to Pteranodon (and other related taxa) and the Istiodactylidae, being closely related to (but not a member of) the Anhangueridae. This specimen further shows a distinct combination of features and is here regarded as belonging to a new taxon, Aussiedraco molnari. The new species shows that distinct pterosaurs are present in the Toolebuc deposits, which so far have yielded most material of flying reptiles from Australia.

\section{ACKNOWLEDGMENTS}

We wish to thank Ralph Molnar (Museum of Northern Arizona, Flagstaff) for several information about Australian fossils and for donating a cast of QM F10613 to the Museu Nacional/UFRJ (Rio de Janeiro). Gareth Dyke (University College Dublin, Ireland) and Antônio Alamo Feitosa Saraiva (Universidade Regional do Cariri, Ceará) for comments on the original version of the ms. We also thank Tamara Fletcher and Steven Salisbury (School of Biological Sciences, University of Queensland, Australia) for discussions on Australian pterosaurs. Lorna Steel (Natural History Museum, London) and Matt Riley (Sedgwick Museum of Earth Sciences, Cambridge) are acknowledged for providing access to specimens under their care and Orlando N. Grillo (Museu Nacional, Rio de Janeiro) for helping with the photographs. This study was partially funded by the Conselho Nacional de Desenvolvimento Científico e Tecnológico (CNPq - grants 140407/2007-3 and 290019/ 2008-7 to T Rodrigues and 307276/2009-0 to AWA Kellner), Coordenação de Aperfeiçoamento de Pessoal de Nível Superior (CAPES - grant to FR Costa) and Fundação Carlos Chagas Filho de Amparo à Pesquisa do Estado do Rio de Janeiro (FAPERJ - grant E-26/ 102.779/2008 to AWA Kellner). T Rodrigues acknowledges the support of the Deutscher Akademischer Austauschdienst (DAAD - grant A/08/71633). 


\section{RESUMO}

Répteis voadores da Austrália são muito raros e, na maioria dos casos, representados por ossos isolados procedentes da Formação Toolebuc (Cretáceo, Albiano), da região leste de Queensland. Entre os primeiros espécimes de pterossauros coletados nestes depósitos encontra-se uma sínfise mandibular que alguns autores acreditaram possuir afinidades com formas encontradas no Cambridge Greensand (Cenomaniano) da Inglaterra. O exemplar acabou sendo classificado como representando uma espécie pertencente ou proximamente relacionada aos gêneros Ornithocheirus, Lonchodectes ou Anhanguera. Neste trabalho nós redescrevemos este espécime e demonstramos que o mesmo não pode ser referido aos gêneros mencionados, mas representa uma nova espécie de pteranodontóide (sensu Kellner 2003), aqui denominada de Aussiedraco molnari gen. et sp. nov. Este exemplar constitui a segunda espécie de pterossauro da Austrália a ser denominada e confirma a que os depósitos de Toolebuc são até o momento os mais importantes para a pesquisa de pterossauros desse país.

Palavras-chave: Pteranodontoidea, Pterosauria, Formação Toolebuc, Cretáceo, Austrália.

\section{REFERENCES}

ANDRES B AND Ji Q. 2006. A new species of Istiodactylus (Pterosauria, Pterodactyloidea) from the Lower Cretaceous of Liaoning, China. J Vert Paleont 26: 70-78.

BennetT SC. 1994. Taxonomy and systematics of the Late Cretaceous pterosaur Pteranodon (Pterosauria, Pterodactyloidea). Occ Pap Nat Hist Mus 169: 1-70.

Costa FR And Kellner AWA. 2009. On two pterosaur humeri from the Tendaguru beds (Upper Jurassic, Tanzania). An Acad Bras Cienc 81: 813-818.

EDMUND AG. 1960. Tooth replacement phenomena in the lower vertebrates. Contributions to Life Science, Royal Ontario Museum 52: 1-190.

FLeTCher TL AND SALISBURY SW. 2010. New pterosaur fossils from the Early Cretaceous (Albian) of Queensland, Australia. J Vert Paleont 30: 1747-1759.

Frey E, Martill DM and Buchy M-C. 2003. A new crested ornithocheirid from the Lower Cretaceous of northeastern Brazil and the unusual death of an unusual pterosaur. In: Buffetaut E AND MAZIN J-M (Eds), Evolution and Palaeobiology of Pterosaurs. Geol Soc, London, Spec Pub 217: 55-63.

Howse SCB, Milner AR AND Martill DM. 2001. Pterosaurs. In: MARTILL DM AND NAISH D (Eds),
Dinosaurs of the Isle of Wight. Pal Ass, Field Guides to Fossils 10: 324-335.

IBRAHIM N, UNWIN DM, MARTILL DM, BAIDDER L AND Zouhri S. 2010. A New Pterosaur (Pterodactyloidea: Azhdarchidae) from the Upper Cretaceous of Morocco. PLoS ONE 5(5): e10875. doi:10.1371/journal.pone.0010875

Kear BP, DeAcon GL and Siverson M. 2010. Remains of a Late Cretaceous pterosaur from the Molecap Greensand of Western Australia. Alcheringa 34: 273-279.

Kellner AWA. 2003. Pterosaur phylogeny and comments on the evolutionary history of the group. In: BUfFETAUT E AND MAZIN J-M (Eds), Evolution and Palaeobiology of Pterosaurs. Geol Soc, London, Spec Pub 217: 105137.

Kellner AWA. 2010. Comments on the Pteranodontidae (Pterosauria, Pterodactyloidea) with the description of two new species. An Acad Bras Cienc 82: 1063-1084.

Kellner AWA, Rich TH, Costa FR, Vickers-Rich P, Kear BP, Walters M AND Kool L. 2010. New isolated pterosaur bones from the Albian Toolebuc Formation (western Queensland, Australia) with comments on the Australian pterosaur fauna. Alcheringa 34: 219-230.

Molnar RE AND Pledge NS. 1980. A new theropod dinosaur from South Australia. Alcheringa 4: 281-287.

Molnar RE AND THUlborn RA. 1980. First pterosaur from Australia. Nature 288: 361-363.

Molnar RE AND Thulborn RA. 2007. An incomplete pterosaur skull from the Cretaceous of North-Central Queensland, Australia. Arq Mus Nac 65: 461-470.

MYERS TS. 2010. A new ornithocheirid pterosaur from the Upper Cretaceous (Cenomanian-Turonian) Eagle Group of Texas. J Vert Paleont 30: 280-287.

RICH TH AND RICH PV. 1989. Polar dinosaurs and biotas of the Early Cretaceous of southeastern Australia. Natl Geogr Res 5: 15-53.

SAYÃo JM AND Kellner AWA. 2000. Description of a pterosaur rostrum from the Crato Member, Santana Formation (Aptian-Albian) Northeastern Brazil. Bol Mus Nacl, série Geologia 54: 1-8.

SeEley HG. 1870. The Ornithosauria: an elementary study of the bones of pterodactyls, made from fossil remains found in the Cambridge Upper Greensand, and arranged in the Woodwardian Museum of the University of Cambridge. Cambridge: Deighton, Bell, and co. xii+135 p.

UNWIN DM. 2001. An overview of the pterosaur assemblage from the Cambridge Greensand (Cretaceous) of Eastern England. Mitt Mus Nat kd Berl, Geowiss Reihe 4: 189 221. 
UNWIN DM. 2003. On the phylogeny and evolutionary history of pterosaurs. In: Buffetaut E AND MAZIN J-M (Eds), Evolution and Palaeobiology of Pterosaurs. Geol Soc, London, Spec Pub 217: 139-190.

UNWIN DM AND HEINRICH W-D. 1999. On a pterosaur jaw from the Upper Jurassic of Tendaguru (Tanzania). Mitt Mus Nat kd Berl, Geowiss Reihe 2: 121-134.

UNWIN DM, LÜ J AND BAKHURINA NN. 2000. On the systematic and stratigraphic significance of pterosaurs from the Lower Cretaceous Yixian Formation (Jehol Group) of Liaoning, China. Mitt Mus Nat kd Berl, Geowiss Reihe 3: $181-206$.

Wang X, Campos DA, Zhou Z and Kellner AWA. 2008. A primitive istiodactylid pterosaur (Pterodactyloidea) from the Jiufotang Formation (Early Cretaceous), northeast China. Zootaxa 1813: 1-18.
Wang X, Kellner AWA, Jiang S, Cheng X, Meng X AND Rodrigues T. 2010. New long-tailed pterosaurs (Wukongopteridae) from western Liaoning, China. An Acad Bras Cienc 82: 1045-1062.

Wang X, Kellner AWA, Jiang S and Meng X. 2009. An unusual long-tailed pterosaur with elongated neck from western Liaoning of China. An Acad Bras Cienc 81: 793-812.

Wellnhofer P and Buffetaut E. 1999. Pterosaur remains from the Cretaceous of Morocco. Palaeontol Z 73: $133-142$.

WILD R. 1990. Ein Flugsaurierrest (Reptilia, Pterosauria) aus der Unterkreide (Hauterive) von Hannover (Niedersachsen). N Jb Geol Paläont Abh 181: 241-254. 